\title{
Obraz islamu w słoweńskich dziennikach „Delo” i „Dnevnik” w pierwszym tygodniu po atakach terrorystycznych na World Trade Center i Pentagon na tle historii kontaktów Słoweńców z muzułmanami
}

\section{Wprowadzenie}

Niniejszy artykuł jest poświęcony obrazowi islamu i muzułmanów po atakach terrorystycznych z 11 września 2001 r. z perspektywy dwóch czasopism należących do prasy codziennej, ukazującej się na terenie Republiki Słowenii. Ze względu na niewielką objętość tekstu zostały zastosowane ograniczone ramy czasowe, jak również uległ zawężeniu zakres wybranego materiału prasowego.

Analiza słoweńskojęzycznych czasopism została przeprowadzona na podstawie artykułów prasowych opublikowanych w dziennikach „Delo” oraz „Dnevnik”. Wyżej wymienione tytuły ukazują się na terenie całego kraju. Zarówno w przypadku dziennika „Delo”, jak i dziennika „Dnevnik” główne wydania pojawiają się regularnie od poniedziałku do soboty. Oba czasopisma posiadają też specjalne wydania niedzielne - „NeDelo” oraz „Nedeljski Dnevnik”. W przypadku czasopisma „Dnevnik” warto także wspomnieć o kulturalno-rozrywkowym dodatku pod nazwą „Zelena Pika”, który ukazuje się w każdy czwartek.

Ramy czasowe bieżącej analizy zostały zawężone do pierwszego tygodnia po atakach terrorystycznych na nowojorskie Światowe Centrum Handlu (World Trade Center - WTC) oraz waszyngtońską siedzibę Departamentu Obrony Stanów Zjednoczonych, znaną jako Pentagon. Decyzja związana z krótkim zakresem czasu łączy się z limitowanymi wymiarami artykułu, jak również z największą ilością informacji przekazywanych w pierwszych siedmiu dniach po atakach z 11 września $2001 \mathrm{r}$.

\section{Historia relacji Słoweńców z islamem}

Na potrzeby analizy obrazu islamu w wyżej wymienionych słoweńskojęzycznych dziennikach należy najpierw przyjrzeć się, jak wyglądały kontakty Słoweńców z muzułmanami i jak kształtowały się one pod wpływem najważniejszych wydarzeń historycznych, gdyż to one miały wpływ na obraz islamu i muzułmanów w tym społeczeństwie.

Wypowiadając się na temat stosunków międzykulturowych zachodzących między Słoweńcami a szeroko pojmowanymi wyznawcami islamu, należy mieć na uwadze fakt, iż przodkowie dzisiejszych mieszkańców Republiki Słowenii 
przez kilka stuleci w ogóle mieli nikłą styczność z muzułmanami ${ }^{1}$. Ziemie słoweńskie nigdy nie leżały $\mathrm{w}$ granicach Imperium Osmańskiego ${ }^{2}$ oraz znajdowały się w relatywnie dużej odległości od terenów dzisiejszej Bośni i Hercegowiny, które po podbojach osmańskich zamieszkiwali w znacznym stopniu potomkowie konwertytów na islam³.

Choć Ahmed Pašić podkreśla, iż pierwsze zetknięcie przodków dzisiejszych Słoweńców z wyznawcami islamu miało miejsce bardzo wcześnie, a mianowicie na przełomie VII i VIII w. ${ }^{4}$, to dochodziło wówczas tylko do krótkotrwałych kontaktów o charakterze handlowym między południowymi Słowianami a muzułmańskimi przybyszami z szeroko pojmowanej Arabii ${ }^{5}$. Pašić przytacza również informację na temat sojuszy południowosłowiańskich dowódców wojskowych z arabskimi muzułmanami, zawiązywanych przeciwko silnemu zagrożeniu, jakie wówczas stanowiło Bizancjum ${ }^{6}$.

Kolejna styczność schrystianizowanych już Słoweńców z wyznawcami islamu miała miejsce wiele wieków później, między pierwszą połową XV a drugą połową XVI w. ${ }^{7}$ Wówczas nastąpiła seria powtarzających się ataków tureckich na tereny zamieszkiwane przez słoweńskojęzyczną ludność. Jednakże na podstawie analiz źródeł historycznych Pašić doszedł do wniosku, iż powyższe napady miały w głównej mierze charakter rabunkowy ${ }^{8}$. Badacz ten zwraca również uwagę na teorię, wedle której już wtedy nadrzędny cel atakujących Turków stanowiło przetarcie szlaków do Wiednia, zatem brak było zainteresowania ziemiami zamieszkanymi przez Słoweńców. Stwierdza jednak, iż występuje zbyt mała liczba źródeł, które mogłyby poświadczyć jej wiarygodność9

Dalsze dzieje relacji Słoweńców z wyznawcami islamu przypadają dopiero na XIX w. Szczególne znaczenie w tej kwestii przypisywane jest okresowi istnienia Prowincji Iliryjskich w latach $1809-1816^{10}$, a następnie rozpoczęciu

\footnotetext{
${ }^{1}$ A. Pašić, Islam in Muslimani v Sloveniji, Tržič 2005, s. 52-68.

${ }^{2}$ Między drugą połową XIII w. a rokiem 1918 ziemie dzisiejszej Słowenii znajdowały się na terenie monarchii Habsburgów, która stanowiła przeciwległą siłę polityczną i wojskową w stosunku do Imperium Osmańskiego. Por. J. Skowronek, M. Tanty, T. Wasilewski, Stowianie Potudniowi i Zachodni, VI-XX wiek, Warszawa 2005, s. 117-129, 145-261, 403-481; H. Wereszycki, Historia Austrii, Wrocław 1986, s. 30-32, 284-285.

${ }^{3}$ J. Skowronek, M. Tanty, T. Wasilewski, op. cit., s. 117-129, 145-261, 403-481.

${ }^{4}$ A. Pašić, op. cit., s. 47.

${ }^{5}$ Ibidem.

${ }^{6}$ Ibidem, s. $47-48$.

${ }^{7}$ Ibidem, s. $52-58$.

${ }^{8}$ Ibidem, s. 54.

${ }^{9}$ Ibidem.

${ }^{10}$ Nazwą „Prowincje Iliryjskie” określa się ziemie odebrane Habsburgom przez wojska napoleońskie w efekcie przegranych wojen z Francją. W granicach Prowincji Iliryjskich znajdowały się tereny dzisiejszej Słowenii, jak również w mniejszym stopniu Chorwacji oraz Włoch. Por. P. Vodopivec, Od Pohlinove slovnice do samostojne države, Ljubljana 2010, s. 20-27; P. Štih, V. Simoniti, P. Vodopivec, Slovenska zgodovina. Družba - polityka - kultura, Ljubljana 2009, s. 250-252.
} 
w 1878 r. okupacji austro-węgierskiej na terenach dzisiejszej Bośni i Hercegowiny $^{11}$. Związane $\mathrm{z}$ istnieniem Prowincji Iliryjskich surowe rządy władz napoleońskich nie zdobyły uznania wśród lokalnej ludności słoweńskojęzycznej, jednak to wówczas miał miejsce rozwój edukacji na szczeblu lokalnym, jak również zainicjowanie możliwości prowadzenia szkolnych lekcji w językach regionalnych ${ }^{12}$. Mimo iż tereny zamieszkiwane przez wyznawców islamu nie leżały w granicach Prowincji Iliryjskich, echa działań władz napoleońskich sięgały granic Imperium Osmańskiego ${ }^{13}$, a krótki żywot Prowincji został zakończony przywróceniem habsburskiej władzy absolutnej ${ }^{14}$. Warto jednak zwrócić uwagę, że w owym momencie miała miejsce wzmożona migracja ze wsi do miast i tym samym nastąpił wzrost znaczenia języków należących do tak zwanych małych narodów ${ }^{15}$. Efektem powyższych przeobrażeń społeczno-kulturowych był rozkwit ideologii narodotwórczych wśród południowych Słowian oraz tym samym wzrost znaczenia działalności słowiańskojęzycznej inteligencji ${ }^{16}$.

W drugiej połowie XIX w. okupacja terenów Bośni i Hercegowiny przez władze habsburskie doprowadziła do zwiększenia zasięgu tej działalności. Wówczas południowosłowiańscy muzułmanie znajdowali się w skomplikowanej sytuacji, w związku z którą decydowali się na przyjęcie tożsamości serbskiej lub chorwackiej ${ }^{17}$. Mimo wzmożonej wymiany intelektualnej między przedstawicielami różnych narodów słowiańskich kontakty przedstawicieli słoweńskiej inteligencji z bośniacko-muzułmańską elitą ograniczały się wyłącznie do podróży odbywanych przez przypadkowe jednostki, w głównej mierze zaliczane do tak zwanej artystycznej bohemy ${ }^{18}$.

Następna styczność Słoweńców z południowosłowiańskimi muzułmanami przypadła na czasy I wojny światowej oraz pierwszego państwa jugosłowiańskiego - w latach trwania walk zarówno Słoweńcy, jak i bośniaccy muzułmanie zasilali szeregi wojska austro-węgierskiego ${ }^{19}$. Nadzwyczaj waleczni Bośniacy otrzymali od władz austriackich nagrodę w postaci meczetu, który stanął

${ }^{11}$ W roku 1878 imperium Habsburgów zaczęło okupować tereny dzisiejszej Bośni i Hercegowiny. Bośniacko-hercegowińskie terytorium formalnie mieściło się $\mathrm{w}$ granicach państwa Osmanów, lecz faktyczną władzę sprawowali Austriacy. W roku 1908 nastąpiła aneksja Bośni i Hercegowiny do Austro-Węgier. Por. H. Wereszycki, op. cit., s. 241-244, 260.

${ }^{12}$ P. Štih, V. Simoniti, P. Vodopivec, op. cit., s. 250-254.

${ }^{13}$ P. Vodopivec, op. cit., s. 20-27; P. Štih, V. Simoniti, P. Vodopivec, op. cit., s. 250-252.

${ }^{14}$ Ibidem, s. 255-256.

${ }^{15} \mathrm{H}$. Wereszycki, op. cit., s. 178.

${ }^{16}$ P. Vodopivec, op. cit., s. 14-20; J. Rapacka, Godzina Herdera. O Serbach, Chorwatach i idei jugosłowiańskiej, Warszawa 1995, s. 9-95.

${ }^{17}$ Ibidem.

${ }^{18}$ Jedną z takich postaci był słoweński poeta doby realizmu Anton Aškerc. Zbiory poezji jego autorstwa zawierają wiersze o tematyce związanej z islamem. Por. A. Aškerc, Zbrano delo, Ljubljana 1951; J. Kos, Duhovna zgodovina Slovencev. Ljubljana 1996, s. 195-202.

${ }^{19}$ A. Pašić, op. cit., s. $68-82$. 
w miejscowości Log pod Mangartom, znajdującej się obecnie na terenie słoweńskiego Przymorza ${ }^{20}$. Meczet został jednak szybko spalony, a bośniackie oddziały zostały przeniesione na inne fronty ${ }^{21}$.

W roku 1918 powstało pierwsze samodzielne państwo tworzone przez południowych Słowian, czyli Królestwo Serbów, Chorwatów i Słoweńców, które w roku 1929 zostało przemianowane na Królestwo Jugosławii ${ }^{22}$. Słoweńcy po raz pierwszy znaleźli się $\mathrm{w}$ jednym organizmie państwowym $\mathrm{z}$ przedstawicielami chrześcijańskiego prawosławia, jak również z wyznawcami islamu. Jednak analogicznie do lat 1878-1908 stosunki Słoweńców z wyznawcami innych religii ograniczały się wyłącznie do pojedynczych kontaktów ${ }^{23}$.

Po zakończeniu II wojny światowej i odniesieniu zwycięstwa przez bałkańskich socjalistycznych partyzantów Słowenia po raz drugi znalazła się w granicach południowosłowiańskiej jednostki państwowej. W roku 1948 władze Socjalistycznej Federacyjnej Republiki Jugosławii z Josipem Broz Tito na czele doprowadziły do oficjalnego zerwania stosunków politycznych ze Związkiem Radzieckim ${ }^{24}$. W związku z powyższym mieszkańcy uboższych republik mieli możliwość zewnętrznej emigracji, jak również wewnętrznej - na tereny najbogatszych republik, czyli Słowenii i Chorwacji ${ }^{25}$. Wówczas po raz pierwszy na ziemiach słoweńskich pojawili się imigranci wyznający islam. Największa fala migracji miała miejsce na przełomie lat 60. i 70. XX w., w momencie powstawania nowych zakładów pracy. Większość ludności napływowej wywodziła się z terenów Bośni i Hercegowiny, które w znaczącym stopniu są zamieszkiwane przez wyznawców islamu. Na tereny Słowenii przybywali również muzułmanie z Macedonii i Kosowa ${ }^{26}$.

Dzisiejsza mniejszość muzułmańska żyjąca na terenie Republiki Słowenii w głównej mierze wywodzi się z napływu owych wewnętrznych gastarbeiterów. Niewielki procent stanowią również uchodźcy z czasów wojny po rozpadzie Jugosławii (toczonej w latach 1991-1995) ${ }^{27}$ oraz niegdysiejsi arabscy studen-

${ }^{20}$ F.M. Dolinar, A. Gabrič, B. Golec, M. Kosi, T. Nabergoj, M. Rihtaršič, Slovenski zgodovinski atlas, Ljubljana 2011, s. 200-240.

${ }^{21}$ A.H. Žerdin, Minaret nad Alpami, „Mladina”, 20.08.2002, http://www.mladina.si/92396/minaret/, dostęp 7.07.2018.

${ }^{22}$ W. Walkiewicz, Jugosławia, Warszawa 2009, s. 42, 85.

${ }^{23}$ A. Pašić, op. cit., s. 52-66.

${ }^{24}$ N. Malcolm, Bosnia: A Short Story, New York 1994, s. 193-194.

${ }^{25}$ J. Malačič, Zunanje migracije Slovenije po drugi svetovni vojni, „Zgodovinski casopis” 45/2, 1991, s. 299-313, za: S. Kalčić, Oblacilne prakse in procesi redefinicije identitete v slovenskih muslimanskih skuplistih po razpadu fugoslavije, nieopublikowana praca doktorska, Ljubljana 2006, s. 44.

${ }^{26} \mathrm{~J}$. Kodelja, Iz katerih obmocij fugoslavije so prihajali, kje v Sloveniji sos e naselili, „IB revija” 26, 1992, s. 1-2, za: T. Pezdir, Transnacionalne aktivnosti - primer migrantov iz Bosne in Hercegovine in njihovih potomcev v Sloveniji, "Casopis za kritiko zanosti, domislijo in novo antropologijo”, 217/218 (rok 32), Ljubljana 2004, s. 184-194.

${ }^{27}$ N. Vrečer, Vsakdanje življenje beguncev in begunk $v$ Sloveniji, Ljubljana 1999, s. 322, za: S. Kalčić, Nisem jaz Barbika - Oblačilne prakse, islam in identitetni procesi med Bošnjaki $v$ Sloveniji, Ljubljana 2007, s. 50. 
ci, którzy kształcili się na słoweńskich uczelniach wyższych ${ }^{28}$. Obecna liczba muzułmanów zamieszkujących tereny Słowenii waha się w granicach 50 000, co stanowi ok. 2,5\% ogółu ludności kraju ${ }^{29}$.

\section{Metodologia}

Analiza artykułów prasowych z dzienników „Delo” i „Dnevnik” została $\mathrm{w}$ niniejszym artykule dokonana przede wszystkim z perspektywy kulturoznawczej, czyli współczesnych teorii naukowych z dziedziny antropologii kultury, ale również socjologii i politologii. Podstawowa problematyka obejmuje zagadnienia związane z pojęciami „swojego” i „obcego”, „orientalizmu” i „zderzenia cywilizacji”, jak również „ramowania”.

\section{„Swój” i „obcy”}

Przy omawianiu kwestii związanej z pojęciami „swojego” i „obcego” warto zwrócić szczególną uwagę na koncepcje powiązane z łączeniem tego zagadnienia z problematyką ogólnie pojmowanej religijności. Haidar Ibrahim Ali stwierdza, iż z punktu widzenia religijnego objawienia poznanie prawdy łączy się z jednoczesnym przestawieniem „innego” z negatywnego punktu widzenia $^{30}$. Dzięki temu wiara w siłę stwórczą stanowi przywilej uświadomionych „swoich”, w przeciwieństwie do nieuświadomionych „obcych”, skazanych na życie w chaosie ${ }^{31}$. Sytuacja ta doprowadza do kładzenia zdecydowanie większego nacisku na obrazy „obcego” aniżeli na wnioski z własnych doświadczeń zdobytych w kontaktach z przedstawicielami odmiennych kultur. Aleksander Hertz zauważa, że obrazy te powstały na drodze doświadczeń przekazywanych przez innych członków danej grupy i nie tworzą wiarygodnej prezentacji sytuacji panującej poza gronem tak zwanych swoich ${ }^{32}$. W związku z powyższym postawa tego typu generuje stereotypy, które tworzą grupową „mądrość”, niemającą niemal żadnego realnego związku z rzeczywistością ${ }^{33}$.

W momencie rozpatrywania problematyki dotyczącej „swojskości” i „obcości” należy również zaznajomić się z pojęciem stereotypu. Termin „stereotyp” został po raz pierwszy użyty przez Waltera Lippmana. Według jego teorii, stereotyp pojawia się wtedy, kiedy ludzkie postawy i stany emocjonalne stanowią

${ }^{28}$ A. Pašić, op. cit.

${ }^{29}$ Ch. Moe, Slovenia, [w:] Yearbook of Muslims in Europe, eds O. Scharbrodt, S. Akgönül, A. Alibašić, J.S. Nielsen, E. Račius, Vol. 10, Leiden 2019, s. 616.

${ }^{30}$ H.I. Ali, The Other's Image, The Sociology of Difference, [w:] Imaging the Arab Other. How Arabs and Non-Arabs View Each Other, ed. T. Labib, London-New York 2008, s. 19.

${ }^{31}$ Ibidem.

${ }^{32}$ A. Hertz, Żydzi w kulturze polskiej, Warszawa 1988, s. 238.

${ }^{33}$ Ibidem. 
reakcję na konkretny zbiór słów, bez odwołania do właściwego stanu rzeczy na podstawie osobistych doświadczeń ${ }^{34}$. Z kolei Paweł Brzozowski zauważa, iż charakterystyczną cechę stereotypu stanowi jego nieelastyczność, dzięki czemu często operują nim jednostki dogmatyczne ${ }^{35}$. Warto również przedstawić punkt widzenia Jerzego Jarcy i Grażyny Dolińskiej, którzy zwracają uwagę na fakt, iż stereotyp w podejściu społeczno-kulturowym tworzą elementy wiedzy o otaczającym świecie - ustalone przez członków danej grupy społecznejej.

\section{Ramowanie (framing)}

Przy analizie obrazu islamu w słoweńskich dziennikach przydatne jest pojęcie „ramowania” ${ }^{37}$. Termin ten został po raz pierwszy użyty przez Roberta Entmana w roku 1993. Wedle uczonego „ramowanie angażuje tworzenie pewnych aspektów rzeczywistości poprzez selekcję i tym samym przez nadawanie im ważności” ${ }^{38}$. Innymi słowy, ramowanie oznacza szczególną postać selekcji, która polega na dokładnym wyborze poszczególnych aspektów z konkretnie postrzeganej współczesnej sytuacji społeczno-politycznej, jak również podkreślanie ich ważności z komunikacyjnego punktu widzenia oraz swoistą promocję prezentowanej definicji ${ }^{39}$. Trzy najważniejsze zadania, które spełnia ramowanie stanowią: definiowanie zagadnień, osądzanie kwestii moralnych jak również sugerowanie metod służących rozwiązywaniu prezentowanych problemów ${ }^{40}$.

W przypadku zjawiska ramowania islam stanowi jeden $\mathrm{z}$ czołowych tematów, które szablonowo odzwierciedlają typowe cechy charakteryzujące procesy ze specyficzną dla niego manipulacją. Daniel Meier jasno stwierdził, iż $\mathrm{w}$ przypadku artykułów prasowych związanych z islamem „podejmowane tematy zazwyczaj ograniczają się do ataków przemocy, międzynarodowego terroryzmu oraz złego traktowania kobiet" ${ }^{\text {"41 }}$.

${ }^{34}$ W. Lippman, Public Opinion, New York 1922, s. 20, za: ibidem.

${ }^{35} \mathrm{P}$. Brzozowski, Relacje między wartościami w świetle badań dyferencjałem semantycznym, [w:] Zagadnienia leksykalne i aksjologiczne. Jęzk a kultura, red. J. Puzynina, J. Bartmiński, t. 2, Wrocław 1991, s. 235-256; S.M. Prochorowa, Stereotyp językowy Europejczyka w kontekście opozycji „swój-obcy”. Stereotyp jako przedmiot lingwistyki. Teoria, metodologia, analizy empiryczne, [w:] Jezyk a kultura, t. 12: Stereotyp jako przedmiot lingwistyki: teoria, metodologia, analizy empiryczne, red. J. Anusiewicz, J. Bartmiński, Wrocław 1998, s. 238.

${ }^{36}$ J. Jarco, G. Dolińska, Wprowadzenie, [w:] Polskie stereotypy i uprzedzenia, red. J. Jarco, G. Dolińska, Wrocław 2002, s. 10.

${ }^{37} \mathrm{~W}$ anglojęzycznym oryginale termin „ramowanie” brzmi framing. Termin „ramowanie” stanowi tłumaczenie autorki tekstu.

${ }^{38}$ H. Rane, J. Ewart, J. Martinkus, Introduction, [w:] Media Framing of the Muslim World, Conflicts, Crises and Contexts, eds H. Rane, J. Ewart, J. Martinkus, London 2014, s. 6.

${ }^{39}$ Ibidem.

${ }^{40}$ R. Entman, Framing: Toward the Clarification of a Fractured Paradigm, ,Journal of Communication", December 1993, s. 15, za: H. Rane, op. cit., s. 6.

${ }^{41}$ D. Meier, Islam in the Media, [w:] Media Power and Religions. The Challenge Facing Intercultural Dialogue and Learning, eds M.L. Pirner, J. Lahnemann, Frankfurt am Main 2013, s. 40. 


\section{Zderzenie cywilizacji i orientalizm}

Przy rozpatrywaniu kwestii powiązanych z obrazem ogólnie pojmowanej kultury obcej należy pokrótce przedstawić dwie teorie, które swego czasu wywołały liczne kontrowersje - zarówno w środowiskach naukowych, jak i w świecie polityki i mediów. Pierwsza z nich to koncepcja Edwarda W. Saida, powszechnie znana jako orientalizm. Jest ona odzwierciedleniem treści czołowej publikacji Saida o tym samym tytule. Druga natomiast, na analogicznej zasadzie, bezpośrednio odwołuje się do książki Samuela Huntingtona Zderzenie cywilizacji.

Edward W. Said zdefiniował orientalizm jako „zbiór instytucji zajmujących się Orientem, czyli wypowiadających się na jego temat, wyrażających autorytatywne poglądy, opisujących go, nauczających o nim, zasiedlających go i rządzących nim"42. Główny przedmiot analizy Saida stanowiły najważniejsze pozycje literatury i filozofii zachodnioeuropejskiej, które mimo różnorodnych korzeni i często odmiennej tematyki łączył wspólny mianownik - obawa przed „agresywną” i „nieobliczalną” kulturą islamu ${ }^{43}$.

Said, jako obywatel Stanów Zjednoczonych pochodzenia palestyńskiego i jednocześnie chrześcijanin, przedstawiał się jako postać znajdująca się na styku dwóch „systemów cywilizacyjnych” - Zachodu i Orientu ${ }^{44}$. Poza gruntownym wykształceniem ${ }^{45}$ posiadał on swoisty zmysł człowieka pogranicza, dzięki któremu potrafił na podstawie badań naukowych oraz specyficznej intuicji potwierdzić mechanizmy kierujące przedstawicielami zachodnich elit w stwarzaniu obrazu muzułmanina jako obcego.

Samuel Huntington w swojej czołowej pozycji Zderzenie cywilizacji i nowy kształt ładu światowego, jak również częściowo we wcześniejszych publikacjach, wygenerował specyficzną teorię, na podstawie której ustalił, iż po zakończeniu zimnej wojny między światem Zachodu a blokiem wschodnim środek ciężkości przeniesie się na pojedyncze państwa narodowe, które stanowią elementy poszczególnych cywilizacji ${ }^{46}$. Wedle przemyśleń Huntingtona siłę napędową międzynarodowej polityki tworzy nieustanna konfrontacja między „światem cywilizowanym” a „światem zacofanym”, jak również między liberalizmem i konserwatyzmem oraz modernizmem a tradycjonalizmem ${ }^{47}$. W początkowej części swojej najsłynniejszej książki Huntington podaje przykłady, które stano-

${ }^{42}$ E. Said, Orientalizm, Poznań 2005, s. 31.

${ }^{43}$ Por. ibidem.

${ }^{44}$ Edward Said, American professor and literary critic, Encyclopaedia Britannica, https://www. britannica.com/biography/Edward-Said, dostęp 11.07.2018.

${ }^{45}$ Ibidem.

${ }^{46} \mathrm{D}$. Miłoszewska, Zderzenie cywilizacji - mit czy rzeczywistość, https://repozytorium.amu. edu.pl/bitstream/10593/962/1/Zderzenie\%20cywilizacji.pdf, dostęp 12.07.2019; por. S. Huntington, Zderzenie cywilizacji i nowy kształt ładu światowego, Warszawa 1997; idem, Wojna cywilizacji?, „Res Publica Nowa” 1994, nr 2, s. 69.

${ }^{47}$ Ibidem. 
wią dowód na podstawowe znaczenie „zderzenia cywilizacji” oraz jego wpływ na rozwój stosunków międzynarodowych. Zalicza do nich między innymi rozłożenie poparcia dla rozpadającej się i objętej wojną Jugosławii ${ }^{48}$ na trzy strefy cywilizacyjne (Chorwacja wspierana przez Niemcy, Serbia przez Rosję, natomiast Bośnia i Hercegowiny przez Iran) oraz stosunek państw zewnętrznych do bombardowania Bagdadu przez wojska Stanów Zjednoczonych w 1993 r. (przychylny stosunek krajów należących do tak zwanej cywilizacji zachodniej oraz negatywna ocena państw łączonych ze światem islamu $)^{49}$.

\section{Analiza prasy}

Materiał badawczy został podzielony pod kątem tematycznym. Artykuły ukazujące się 12-19 września 2001 r. w dziennikach „Delo” i „Dnevnik” zostały umieszczone w trzech grupach utworzonych na podstawie najczęściej poruszanych tematów w obu powyższych czasopismach, jak również podejścia i kompetencji dziennikarzy.

Pierwsza grupa, „islam a przemoc”, dotyczy artykułów powiązanych z kojarzeniem religii muzułmańskiej z takimi zjawiskami, jak terroryzm, dżihad - błędnie rozumiany jako „święta wojna” - oraz innymi przejawami agresji wynikającymi rzekomo z zasad islamu.

Druga grupa, „islam a zderzenie cywilizacji”, wiąże się z odnoszeniem napiętych stosunków między światem islamu a światem Zachodu do teorii Samuela Huntingtona na temat „zderzenia cywilizacji”, jak również do ogólnego terminu o tej samej nazwie, który uformował się na podstawie powyższej koncepcji. Wówczas zostaną również podjęte zagadnienia związane z „orientalistycznym” spojrzeniem na świat islamu, wedle teorii Edwarda W. Saida.

Trzecia grupa, „pozytywy i negatywy”, łączy się zarówno z przychylnym nastawieniem słoweńskich dziennikarzy do kultury zachodniej i krytycznym odniesieniem do świata islamu, jak również z okazywaniem dezaprobaty w stosunku do działań i postaw ze strony przedstawicieli kultury judeochrześcijańskiej oraz wyrazów uznania dla nastawienia poszczególnych jednostek lub grup społecznych związanych ze światem islamu. Tym samym zostaną rozpatrzone kwestie powiązane z kreowaniem „swojskości i „obcości”.

\section{Islam a przemoc}

W związku z tragedią łączącą się z atakami terrorystycznymi na World Trade Center i Pentagon czołowe miejsce pod kątem tematów i treści zajmują artykuły odnoszące się do problematyki ogólnie pojmowanej przemocy.

${ }^{48}$ Rozpad Jugosławii oraz związana z nim wojna miał miejsce w latach 1991-1995. Por. W. Walkiewicz, op. cit., s. 251-286.

${ }^{49}$ S. Huntington, Zderzenie cywilizacji..., s. 40-42. 
Największą grupę wątków w obu dziennikach stanowią te łączące się z kwestią terroryzmu oraz głównym podejrzanym - Osamą Bin Ladenem ${ }^{50}$, powiązanym z organizacją Al-Kaida. Bin Laden przedstawiany jest w głównej mierze przez pryzmat działalności terrorystycznej, a jego zaangażowanie religijne stanowi kwestię drugoplanową. W artykule Osama Bin Laden plus osumljenih 5 z czasopisma „Delo" ${ }^{1}$ Bin Laden określany jest jako „islamski fundamentalista”, lecz brakuje jakichkolwiek bliższych odniesień wiążących się z jego religijnością ${ }^{52}$. Zdecydowanie większa uwaga poświęcona jest jego zaangażowaniu w działalność wywrotową oraz krajom, w których znajdują się znaczące grupy współpracujące z organizacją Al-Kaida (Iran, Irak, Libia, Sudan, Syria) ${ }^{53}$. Artykuł z czasopisma „Dnevnik” Tudi molk je lahko nevaren sygnalizuje, iż Osama Bin Laden stał się nowym wrogiem i jego główny cel stanowią Stany Zjednoczone $^{54}$. Informuje również o serii ataków, w które zaangażowana była grupa Bin Ladena, jak między innymi podłożenie bomby pod wieże World Trade Center w 1993 r. oraz strzelanina w ambasadzie w Nairobi w 1998 r. ${ }^{55}$ Warto zwrócić uwagę, iż w powyższym artykule ani razu nie pojawia się słowo „islam” ani „muzułmanin” ${ }^{6}$. Jednak forma i treść wyraźnie wskazują na związek Bin Ladena $\mathrm{z}$ odmienną kulturą $\mathrm{w}$ odniesieniu do atakowanego świata Zachodu. Widoczne są również zamienniki stosowane w celu uniknięcia słownictwa związanego z islamem. Wśród nich czołową pozycję zajmuje określenie „fanatyczny arabski terroryzm”, które zawiera wyraźną konotację łączącą się ze światem muzułmańskim ${ }^{57}$.

Z kolei w tekście Obrazi globalnego terorizma ${ }^{58} \mathrm{z}$ dziennika „Delo” znajduje się znacznie więcej odniesień do islamu. Mimo że ukazana w nim Organizacja Wyzwolenia Palestyny (jako jeden z przykładów współczesnych struktur terrorystycznych funkcjonujących na Bliskim Wschodzie) prezentowana jest zarówno z perspektywy świeckiej, jak i religijnej, a określenia wskazujące na wyznanie palestyńskich terrorystów są zdecydowanie bardziej wyraziste. Działacze palestyńskiej organizacji są przedstawiani między innymi jako „islamscy ekstremiści”, a ich działania jako terroryzm islamsko-fundamentalistyczny $^{59}$. Autorzy tekstu zaznaczają również, że „nowe zagrożenia na Bliskim Wschodzie najczęściej wywodzą się z rąk islamskich ekstremistów”"00.

\footnotetext{
${ }^{50}$ Arab. Usama Ibn Ladin - w tekście stosuję najpowszechniejszą w popularnych mediach formę jego nazwiska.

${ }^{51}$ Osama Bin Laden plus oskarżona piątka (tłumaczenie autorki).

${ }^{52}$ Osama Bin Laden plus osumljenih 5, „Delo”, 12.09.2001.

${ }^{53}$ Ibidem.

${ }^{54}$ Tudi molk je lahko nevaren, „Dnevnik”, 15.09.2001.

${ }^{55}$ Ibidem.

${ }^{56}$ Ibidem.

${ }^{57}$ Ibidem.

${ }^{58}$ Twarz globalnego terroryzmu (tłumaczenie autorki).

${ }^{59}$ Obrazi globalnego terorizma, „Delo”, 15.09.2001.

${ }^{60}$ Ibidem.
} 
Kolejny wątek związany z przemocą stanowią opisy prezentujące nieszczęścia, które po atakach na WTC i Pentagon dotknęły stronę amerykańską. Przedstawione są również działania amerykańskich polityków mające na celu normalizację stosunków z krajami z większością muzułmańską oraz zdobycie sojuszników w walce z terroryzmem. Artykuł z czasopisma „Delo” Dan žalovanja za in spomina na žrtve ${ }^{61}$ prezentuje wzmożoną działalność policji na terenie całych Stanów Zjednoczonych oraz pierwsze aresztowania osób podejrzanych o współpracę z organizacjami terrorystycznymi ${ }^{62}$. Mimo iż nie występują nawiązania do islamu jako religii, w przypadku opisywania zatrzymanych podejrzanych jednokrotnie zostało użyte określenie „członkowie radykalnych muzułmańskich organizacji” ${ }^{63}$. Jednak w tekście Powell išče zaveznike ${ }^{64}$, w opisach obejmujących poszukiwanie sojuszników w walce z terroryzmem, występują określenia typu „radykalne islamskie rządy sprawowane przez talibów”, „popieranie przez Pakistan radykalnych islamskich rządów w Afganistanie”65.

Niektóre teksty, jak na przykład artykuł z czasopisma „Dnevnik” Napad na ZDA je napad na VSE ${ }^{66}$, prezentują radykalnie negatywne nastawienie amerykańskich i światowych polityków w stosunku do islamskich terrorystów ${ }^{67}$. Powyższy przykład potwierdza przytoczenie punktu widzenia głównego sefardyjskiego rabina Eliyahu Bakshiego, który „pozwał wszystkich islamskich kleryków wydających fatwy, organizujących samobójcze zamachy i robiących z zamachowców męczenników"68. Jednakże mimo to pojawia się również akcent, który przedstawia islam z całkowicie przeciwnej strony. Tworzy go wypowiedź Abdelouaheda Belkeziza, sekretarza generalnego Organizacji Konferencji Islamskiej, który „potępił napady w USA oraz stwierdził, iż islam jest tą religią, która w największym stopniu ceni ludzkie życie i zakazuje jakichkolwiek nieuzasadnionych zabójstw"69. Interesujący przykład stanowi artykuł z czasopisma „Delo” New York petega dne $e^{70}$, który przedstawia reakcje dzieci szkolnych na wydarzenia z 11 września $^{71}$. W wypowiedziach przytoczonych przez matkę jednego z dzieci znalazły się liczne określenia ukazujące islam przez pryzmat otoczenia, w którym wychowują się najmłodsi amerykańscy muzułmanie. Jedna $z$ wypowiedzi otwarcie stwierdza, że „muzułmanie to fanatycy,

\footnotetext{
${ }^{61}$ Dzień żałoby narodowej oraz wspominania ofiar (tłumaczenie autorki).

${ }^{62}$ Dan žalovanja in spomina na žrtve, „Delo”, 15.09.2001.

${ }^{63}$ Ibidem.

${ }^{64}$ Powell szuka sojuszników (tłumaczenie autorki).

${ }^{65}$ Powell išče zaveznike, „Delo”, 17.09.2001.

${ }^{66}$ Atak na USA to atak na wszystkich (tłumaczenie autorki).

${ }^{67}$ Napad na ZDA je napad na VSE, „Dnevnik”, 13.09.2001.

${ }^{68}$ Ibidem.

${ }^{69}$ Ibidem

${ }^{70}$ Nowy fork piatego dnia (tłumaczenie autorki).

${ }^{71}$ New York petega dne, „Delo”, 17.09.2001.
} 
w związku z czym wszyscy są potencjalnymi terrorystami”72. Autorzy tekstu zwracają uwagę, że w atmosferze powszechnego współczucia, jaka zapanowała po wrześniowej tragedii, można równie łatwo dostrzec rosnącą falę nienawiści, którą na podstawie błędnych stereotypów rozprzestrzeniają „biali” Amerykanie ${ }^{73}$.

\section{Islam a zderzenie cywilizacji}

W sąsiedztwie artykułów bezpośrednio odnoszących się do zjawiska terroryzmu i ogólnie rozumianej przemocy, znajdują się teksty odwołujące się do szerszego kontekstu mającego związek z powyższymi zjawiskami. Tematyka kojarzona z wojną i szeroko pojmowanymi konfliktami, na łamach słoweńskiej prasy codziennej często rozpatrywana jest w oparciu o pojęcie „zderzenia cywilizacji”, nawiązujące do teorii Samuela Huntingtona.

Słoweńskie dzienniki „Delo” oraz „Dnevnik” w pierwszym tygodniu po atakach z 11 września 2001 r. rozpatrywała kwestię „zderzenia cywilizacji” z dwóch perspektyw: współczesnej oraz historycznej. Perspektywa współczesna obejmuje kwestie łączące się z „wypowiedzeniem wojny terrorystom” przez amerykańskie władze, natomiast perspektywa historyczna odwołuje się do zjawisk, które zdaniem dziennikarzy przyczyniły się do zaistniałego stanu rzeczy.

Artykuł z czasopisma „Delo” Schussel svari pred prenaglimi obtožbami ${ }^{74}$ wyraźnie podkreśla brak jasnych celów, który charakteryzuje wszelkie ataki terrorystyczne. Autorzy kategorycznie stwierdzają, iż „nowy terroryzm”, składający się z „ataków terrorystycznych na świat zachodni, jest sam z siebie negatywnie nastawiony” i stanowi „uderzenie w symbole cywilizowanego świata”75. Należy zwrócić uwagę, że chociaż tekst jednoznacznie odwołuje się do pojęcia „zderzenia cywilizacji”, autorzy zastrzegają, iż „nie chodzi o wojnę religijną ani zderzenie cywilizacji” i starają się zachować pozory obiektywności ${ }^{76}$. Jednocześnie podkreślony jest fakt, iż wywrotowe akcje terrorystyczne sieją postrach zarówno wśród obywateli należących do kultury judeochrześcijańskiej, jak również muzułmańskiej ${ }^{77}$. Jednak w celu obiektywnego wyjaśnienia niezrozumiałych motywów kierujących działaniami terrorystów, bez uwzględniania sztywnego podziału na Wschód i Zachód, zostaje paradoksalnie zastosowana nomenklatura nawiązująca do teorii Samuela Huntingtona.

W przypadku tekstu z dziennika „Delo” Začetek vojne med civilizcijami ${ }^{78}$ ukazana jest jednokierunkowa interpretacja „zderzenia cywilizacji”. Zarów-

\footnotetext{
${ }^{72}$ Ibidem.

${ }^{73}$ Ibidem.

${ }^{74}$ Schlussel ostrzega przed gwałtownymi oskarżeniami (tłumaczenie autorki).

${ }^{75}$ Schussel svari pred prenaglimi obtožbami, „Delo”, 14.09.2001.

${ }^{76}$ Ibidem.

${ }^{77}$ Ibidem.

${ }^{78}$ Początek wojny między cywilizacjami (tłumaczenie autorki).
} 
no tytuł, jak i treść nie pozostawiają wątpliwości, iż autorzy mieli na myśli zaprezentowanie ścisłego podziału na „cywilizację Zachodu” i „resztę świata”. W odniesieniu do działań terrorystycznych często pojawiają się takie określenia, jak: „ugrupowania muzułmanów”, „islamski terroryzm” i „prawdziwe oblicze islamskiego terroryzmu”79. Tytułowa „wojna” jest przedstawiona jako „cywilizacyjna wojna fanatyków przeciwko wolnemu światu ludzkich wartości oraz wojna światowa między dobrem a złem" ${ }^{80}$. W związku z powyższym nastawienie autorów nie pozostawia żadnych wątpliwości co do dzielenia przez nich świata na „nowoczesny i tym samym dobry Zachód” oraz „zacofany i tym samym zły Wschód”.

Artykuł z kulturalno-rozrywkowego dodatku „Zelena Pika” do czasopisma „Dnevnik” ZDA pred zgodovinskim razpotjem ${ }^{81}$ autorstwa Primoža Sterbenca podejmuje temat zderzenia cywilizacji z perspektywy historycznej. Autor już w pierwszym akapicie podkreśla, iż „powody antagonistycznego nastawienia do islamskich ugrupowań fundamentalistycznych oraz szerszych warstw islamskiej populacji mają podłoże historyczno-religijne, cywilizacyjno-ideologiczne i bezpośrednio polityczne” ${ }^{\text {. }}$. Zaznacza również, iż „amerykańskie i islamskie pojmowania świata są różnie i wzajemnie do siebie nie przystają ze względu na fakt, że zachodnie pojmowanie świata zbudowane jest na racjonalizmie i sekularyzmie, a podstawę islamskiego światopoglądu tworzy typowo tradycyjne społeczeństwo" ${ }^{83}$. Jednakże Sterbenc w tym samym tekście przytacza informacje na temat wpływu kultury islamu na zdobycze cywilizacji judeochrześcijańskiej. Zwraca uwagę, iż „to właśnie świat islamu przedstawił światu zachodniemu hellenistyczne idee" ${ }^{\text {"4 }}$. Autor szybko jednak wyjaśnia swój punkt widzenia stwierdzając, iż „Zachód przez ostatnie 600 lat rozwinął potężną technologiczną i materialną siłę, podczas gdy islamska społeczność reprezentuje zacofaną część świata" ${ }^{\text {s5 }}$.

Sąsiedni artykuł z czwartkowego dodatku do dziennika „Dnevnik” (,Zelena Pika”) został przygotowany przez Tomaža Bukovca. Autor nadał mu tytuł Strah lahko življenje spremeni v peke ${ }^{86}$ i podobnie jak Primož Sterbenc ukazał problem terroryzmu i zderzenia cywilizacji z perspektywy kluczowych wydarzeń historycznych. Oryginalność postawy Bukovca polega jednak na podjęciu tematu zderzenia cywilizacji poprzez sięgnięcie do czasów pierwszych wyznawców islamu, jak również odniesienia podstawowych zasad zaczerpniętych z VII w.

\footnotetext{
${ }^{79}$ Začetek vojne med civilizacijami, „Delo”, 13.09.2001.

${ }^{80}$ Ibidem.

${ }^{81}$ USA przed historycznym skrzyżowaniem dróg (tłumaczenie autorki).

${ }^{82} \mathrm{P}$. Sterbenc, ZDA pred zgodovinskim razpotjem, „Dnevnik - Zelena Pika”, 15.09.2001.

${ }^{83}$ Ibidem.

${ }^{84}$ Ibidem.

${ }^{85}$ Ibidem.

${ }^{86}$ Strach jest $w$ stanie zmienić $\dot{z} y c i e w$ piekło (tłumaczenie autorki).
} 
do współczesnego islamskiego światopoglądu ${ }^{87}$. Bukovec stwierdza, iż powodem niechęci wyznawców islamu do świata Zachodu jest „długa obecność nie-muzułmanów na ziemiach, na których Mahomet ustanowił najmłodszą monoteistyczną religię, która doprowadziła do wzmocnienia wrogości wobec zachodniej siły”, jak również fakt, że „zachodnia publika ma niewielkie pojęcie na temat sakralności saudyjskiego obszaru" ${ }^{99}$. Bukovec tym samym zaznacza, że skrajna postawa Osamy Bin Ladena łączy się z przekonaniem o „dokonywaniu „amerykańskich zbrodni, które oznaczają jasną amerykańską zapowiedź wojny przeciwko Bogu, jego prorokowi i muzułmanom"90. Mimo iż Bukovec zagłębia się w szczegóły dotyczące historii i kultury islamu, należy zwrócić uwagę, że jego podejście sprowadza się do licznych uogólnień, nawiązujących do teorii Samuela Huntingtona.

\section{„Swój” i „obcy” a sytuacja po 11 września 2001 r. w USA i na świecie}

Ostatnia kwestia podejmowana pod kątem rozpatrywania obrazu islamu w dwóch ogólnokrajowych słoweńskich dziennikach łączy się z przedstawieniem różnych twarzy dwóch rzekomo zantagonizowanych ze sobą kultur. Wbrew pozorom obraz islamu nie zawsze prezentowany jest $\mathrm{z}$ negatywnego punktu widzenia, jak również strona zachodnia nie zawsze ukazywana jest w samych superlatywach.

Artykuł z dziennika „Delo” Bin Ladna živega ali mrtvega $a^{91}$ przedstawia zgoła odmienny problem, jaki stanowi stosunek części Amerykanów wyznających chrześcijaństwo do obywateli Stanów Zjednoczonych wyznających islam ${ }^{92}$. Autorzy podają informacje na temat dwustu napadów mających miejsce zaledwie tydzień po atakach na WTC i Pentagon, których ofiarami stali się przypadkowi amerykańscy muzułmanie. Jednocześnie przytacza opinię ówczesnego prezydenta Stanów Zjednoczonych, George’a W. Busha, który mimo wypowiedzenia otwartej wojny islamskim terrorystom, natychmiast potępił akty wandalizmu skierowane w stronę niewinnych obywateli USA ${ }^{93}$. Autorzy zaznaczają, iż „George W. Bush objaśniał różnicę między terroryzmem a muzułmańską wiarą oraz stwierdził, iż ostatnią rzeczą, której potrzebują amerykańskie organy bezpieczeństwa jest wojna domowa między chrześcijanami a muzułmanami”"94. Tekst zawiera również prezentację reakcji ze strony muzułmańskich przywódców religijnych zamieszkujących Stany Zjednoczone. W związku z powyższym

\footnotetext{
${ }^{87}$ T. Bukovec, Strah lahko življenje spremeni v pekel, „Dnevnik - Zelena Pika”, 15.09.2001.

${ }^{88}$ Ibidem.

${ }^{89}$ Ibidem.

${ }^{90}$ Ibidem

${ }^{91}$ Bin Ladena żywego lub martwego (tłumaczenie autorki).

${ }^{92}$ Bin Ladna živega ali mrtvega, „Delo”, 19.09.2001.

${ }^{93}$ Ibidem.

${ }^{94}$ Ibidem.
} 
autorzy przytaczają wypowiedź jednego z imamów, który oświadcza, iż inni muzułmanie „kochają Amerykę w tym samym stopniu co ja”"95.

Przywołany wcześniej artykuł z czasopisma „Delo” New York petega dne prezentuje podobny problem, który z kolei dotyczy przemocy słownej. Kwestia ta w znaczącym stopniu dotknęła najmłodszych obywateli Stanów Zjednoczonych wyznających islam $^{96}$. Tekst przedstawia wypowiedzi uczniów jednej z nowojorskich szkół, którzy wyrażają swoje obawy w związku z wrogim nastawieniem chrześcijańskich skrajnych konserwatystów. Autorzy ukazują wypowiedź min. młodego Ishana pochodzącego z Indii, który stwierdza, iż ,jest zaniepokojony, ponieważ jego rodzinie grozili właśni sąsiedzi"97. Inny, anonimowy uczeń zakomunikował, iż „podczas jazdy metrem biali Amerykanie wrogo na niego patrzą" 98 . Wyżej wymienione informacje stanowią wyraźne sygnały, które przestrzegają „białą populację” przed fałszywym kreowaniem wizerunku „obcego" oraz traktowaniem islamu jako monolitu.

Artykuł z czasopisma „Dnevnik” Podpora arabskega $a^{99}$ sveta $^{100}$ ukazuje niezgodne z powszechnym stereotypem podejście władz państw ze „świata islamu" do ataków terrorystycznych z 11 września 2001 r. ${ }^{101}$ Treść sygnalizuje, iż „poparcie dla Amerykanów w szukaniu złoczyńców w dużym stopniu pochodzi ze strony władz Egiptu, Arabii Saudyjskiej i Zjednoczonych Emiratów Arabskich" ${ }^{102}$. Warto również przytoczyć cytowaną w tym artykule wypowiedź ajatollaha Mohameda Kaszaniego, który orzekł, że „islam w żadnym stopniu nie popiera tak przerażających napadów" ${ }^{103}$. Cechę szczególną powyższego tekstu stanowi przytoczenie faktów, które są dowodem na to, iż islam nie posiada wyłącznie jednej twarzy, jaką tworzy mroczne oblicze ekstremistów związanych $\mathrm{z}$ atakami terrorystycznymi. Dlatego też istotne jest ukazywanie obrazu „obcego" z różnych perspektyw, nie tylko połączonych z negatywną stroną medalu.

\section{Podsumowanie}

Wyżej zaprezentowane artykuły opublikowane w pierwszym tygodniu po atakach terrorystycznych z 11 września 2001 r. w dwóch słoweńskojęzycznych, ogólnokrajowych dziennikach, „Delo” i „Dnevnik”, zostały ze względu na swoją

${ }^{95}$ Ibidem.

${ }^{96}$ New York petega dne, „Delo”, 17.09.2001.

${ }^{97}$ Ibidem.

${ }^{98}$ Ibidem.

${ }^{99} \mathrm{~W}$ prasie słoweńskiej dość często pojawia się błąd, który polega na sprowadzeniu świata islamu do świata arabskiego - mimo że Arabowie stanowią co najwyżej czwartą część wszystkich muzułmanów w skali globalnej.

${ }^{100}$ Wsparcie ze strony świata arabskiego (tłumaczenie autorki).

${ }^{101}$ Podpora arabskega sveta, „Dnevnik”, 15.09.2001.

${ }^{102}$ Ibidem.

${ }^{103}$ Ibidem. 
zawartość treściową i wymowę ujęte w trzy grupy tematyczne według tematów, które zostały w największym stopniu poruszone. Odnosiły się one bowiem głównie do relacji islamu i przemocy, islamu i zderzenia cywilizacji, a także postrzegania tego, kto jest „swoim”, a kto „obcym” po atakach na WTC i Pentagon.

Należy zauważyć, że autorzy omawianych artykułów większości starali się wyważyć swój obraz islamu i muzułmanów w opisach sytuacji po 11 września 2001 r., unikali identyfikowania islamu z przemocą, a muzułmanów z terrorystami, choć, oczywiście, zdarzały się wyjątki. Zauważali, że świat islamu ma swoje zasługi dla cywilizacji światowej, a muzułmanie nierzadko żyją także w społeczeństwach zachodnich, co sprawia, że nie są „obcymi”. Jedynie koncepcja zderzenia cywilizacji, jak się zdaje, znalazła większy oddźwięk w ich pojmowaniu tego, co wydarzyło się w USA, ale jednocześnie wielu z nich nie obarczało winą jedynie świata islamu, dostrzegając zaszłości historyczne.

Słoweńcy nie mają własnych historycznych negatywnych doświadczeń $\mathrm{z}$ islamem, co znalazło wyraz w numerach dzienników publikowanych zaraz po atakach z 11 września 2001 r. W omawianych artykułach ich autorzy omawiają wyłącznie to, co ma miejsce poza granicami Słowenii i nie odnoszą zaistniałej sytuacji do swojego państwa, a także do - w większości bośniackiej - mniejszości muzułmańskiej mieszkającej na jego terenie. 